\title{
Hairy Cell Leukemia Variant
}

National Cancer Institute

\section{Source}

National Cancer Institute. Hairy Cell Leukemia Variant. NCI Thesaurus. Code C7401.

An indolent chronic B-cell leukemia resembling classic hairy cell leukemia but shows variant cytologic, hematologic, and immunophenotypic features and is resistant to the conventional therapy applied to hairy cell leukemia. Biologically, it is not related to hairy cell leukemia. 